\title{
A simple xanthelasma palpebrarum treatment: Scissor excision
}

\author{
Ksantelazma için basit bir tedavi tekniği: Makasla eksizyon
}

- Tamer İfan Kaya, ๑ Ulaș Güvenç

VM Medical Park Mersin Hospital, Clinic of Dermatology, Mersin, Turkey

1-What is the most common type of cutaneous xanthoma?

Xanthelasma palpebrarum.

2-What are the treatment options for xanthelasma palpebrarum?

Surgical excision, treatment with chemicals, cryotherapy, electrosurgery, laser therapy.

3-Which treatment method leads to the fastest recovery?

Surgical excision and suturing

4-Which treatment method is performed effectively especially in one session?

Surgical excision and suturing.

5-Which one is easier to perform on thin palpebral skin? Scalpel excision or scissor excision?

Scissor excision.

\section{Case Report}

A 40-year-old woman was referred for the treatment of yellowish papules on her upper eyelids, which had been present for more than 1 year. She was previously treated 3 times with cryotherapy without significant improvement. Dermatological examination revealed $6 \mathrm{~mm}$, yellow, flat, soft papules on the medial angles of the both upper eyelids, which were consistent with xanthelasma palpebrarum. Two percent lidocaine with epinephrine was injected for local anaesthesia until the lesions swell (Figure 1). Then the lesions pinched with a tissue forceps and gently pulled up and elevated (Figure 2). The elevated lesions were snipped slowly and symmetrically using the tip of sharp tipped iris scissors (Figure 3). Oval surgical wounds were observed after the excisions (Figure 4). The skin was closed with 2 simple interrupted stitches, using 6/0 polypropylene sutures (Figure 5 ). The patient was advised to gently clean the surgery area twice daily with $10 \%$ povidone-iodine solution. The sutures were removed 5 days postoperatively and sterile skin strips were applied to secure the wounds for additional 5 days.

\section{Discussion}

Various treatment techniques of xanthelasma palpebrarum has been described in the literature which include surgical excision, cryotherapy, electrosurgery, treatment with chemicals and various methods of laser ablation ${ }^{1-5}$.

We have been using the scissor excision technique successfully for several years. This technique has been used by different dermatologists in practice, however it has not been published much. We prefer to use this scissor excision technique in patients with small, compact, papular lesions.

Excision should be planned parallel to the relaxed skin tension lines. Skin laxity of eyelids usually gives the surgeon an opportunity to perform an adequate excision. However, preoperative assessment for scissor excision is important. Very extensive lesions may not be operable. Before the operation, we pinch the lesions. If the lesion is wide enough, we observe an ectropion with this pinch test and in these patients; we prefer destructive treatment methods, instead of

Address for Correspondence /Yazışma Adresi: Tamer Irfan Kaya MD, VM Medical Park Mersin Hospital, Clinic of Dermatology, Mersin, Turkey Phone: +90 5352519660 E-mail: tamerirfankaya@hotmail.com

Received/Geliş Tarihi: 05.12.2018 Accepted/Kabul Tarihi: 06.12.2018 ORCID ID: orcid.org/0000-0002-6821-7199

(C)Telif Hakkı 2018 Deri ve Zührevi Hastalıklar Derneği

Türkderm-Deri Hastalıkları ve Frengi Arșivi Dergisi, Galenos Yayınevi tarafından basılmıștır. 


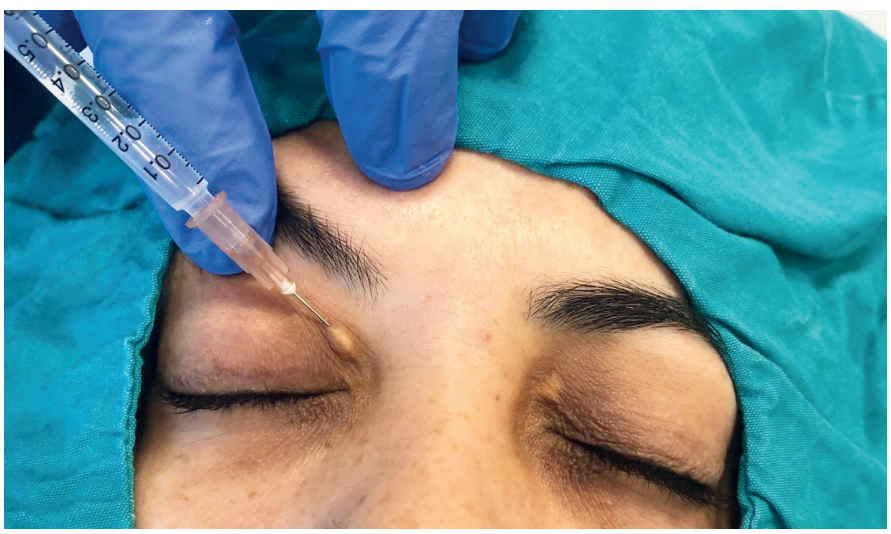

Figure 1. Xanthelasma palpebrarum lesions on the upper eyelids. Local anaesthetics were injected until the lesions swell

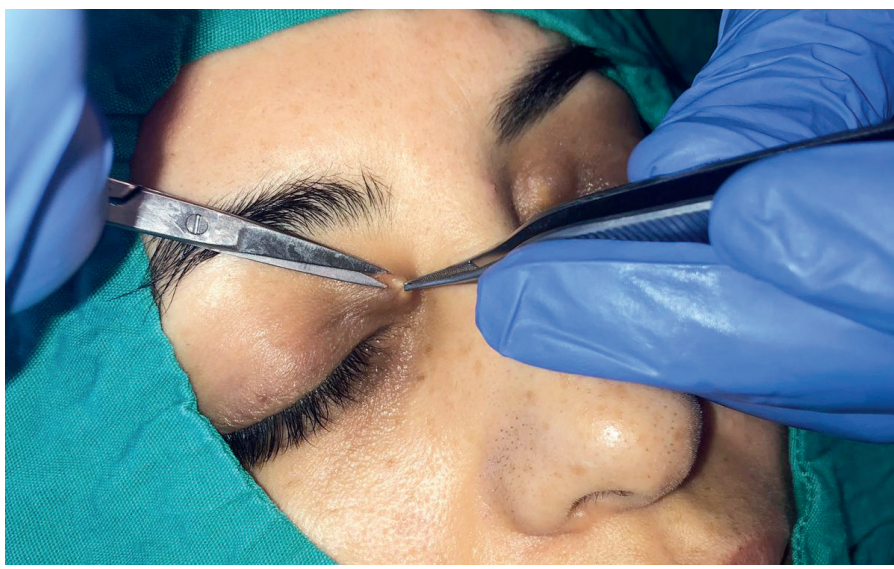

Figure 2. The lesion pinched with a tissue forceps and elevated. The tip of the sharp scissors was used to snip the lesion

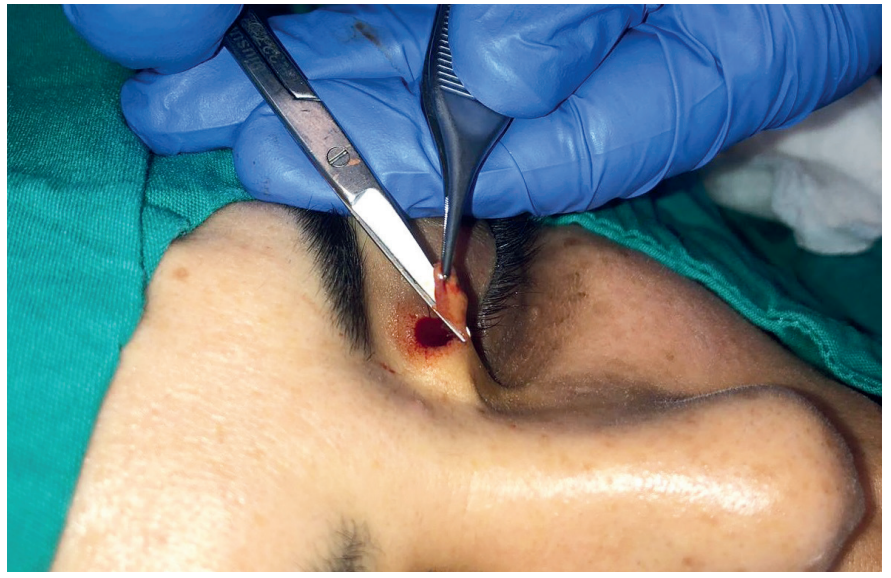

Figure 3. The left lesion was cut almost totally

excision. If the lesion is wide and has a length more than $1 \mathrm{~cm}$ and the patient has redundant upper lid skin, an upper lid blepharoplasty would be a better treatment option for these patients. Excision of lengthy lesions may look like a half blepharoplasty, which should be corrected with a second operation for cosmetically disturbing appearance. We do not advise post-operative topical antibiotic ointment use, since it can cause maceration and interfere with healing. Recurrences are observed

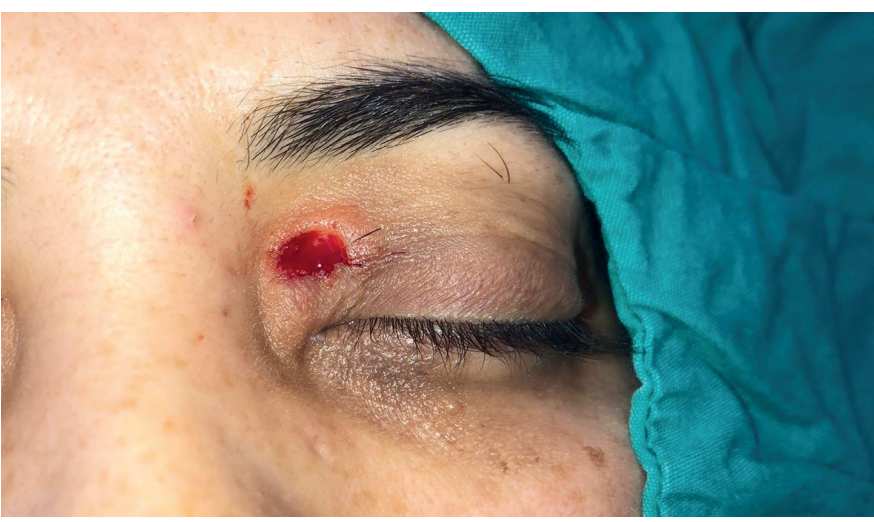

Figure 4. The oval surgical defect

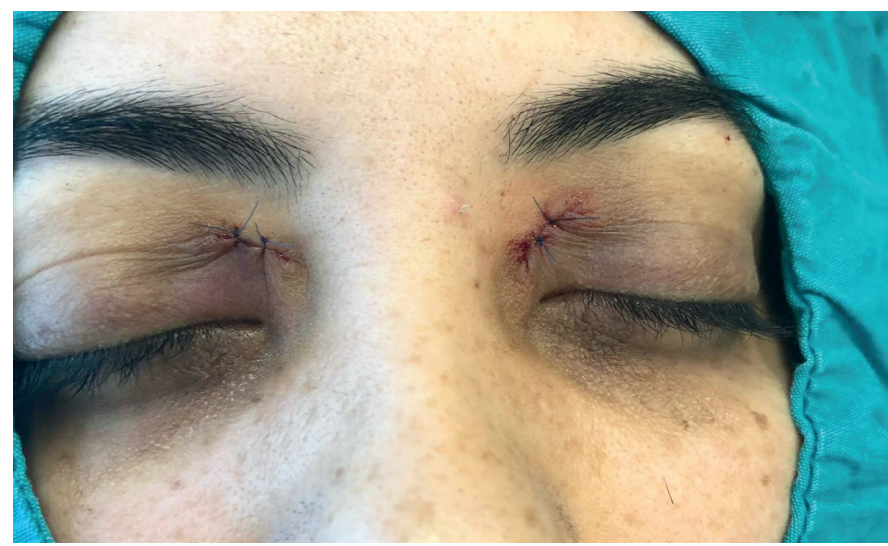

Figure 5. The wounds were closed with 2 simple interrupted stitches, using $6 / 0$ polypropylene sutures

especially in patients with granular widespread lesions. The recovery time of surgery is shorter than other destructive methods which heal with secondary intention. Surgery makes more defined borders, healing more rapidly and resulting in less collateral tissue damage than those produced by destructive treatment methods ${ }^{6}$.

On the basis of our experience, we would like to recommend xanthelasma treatment with scissor excision as an excellent therapeutic alternative to the other described approaches, especially for small, compact, papular lesions. Resultant scars of surgery on the eyelids are mostly aesthetically inconspicuous.

\section{References:}

1. Obradovic B: Surgical Treatment as a First Option of the Lower Eyelid Xanthelasma. J Craniofac Surg 2017;28:678-79.

2. Ullmann $Y$, Har-Shai $Y$, Peled IJ: The use of $\mathrm{CO} 2$ laser for the treatment of xanthelasma palpebrarum. Ann Plast Surg 1993;31:504-7.

3. Rohrich RJ, Janis JE, Pownell PH: Xanthelasma palpebrarum: a review and current management principles. Plast Reconstr Surg 2002;110:1310-4.

4. Labandeira J, Vázquez-Osorio I, Figueroa-Silva O, Pereiro M Jr, Toribio J: Tolerability and effectiveness of liquid nitrogen spray cryotherapy with very short freeze times in the treatment of xanthelasma palpebrarum. Dermatol Ther 2015;28:346-50.

5. Güngör S, Canat D, Gökdemir G: Erbium: YAG laser ablation versus $70 \%$ trichloroacetıc acid application in the treatment of xanthelasma palpebrarum. J Dermatolog Treat 2014;25:290-3.

6. Arashiro DS, Rapley JW, Cobb CM, Killoy WJ: Histologic evaluation of porcine skin incisions produced by CO2 laser, electrosurgery, and scalpel. Int J Periodontics Restorative Dent 1996;16:479-91. 